\title{
A REVIEW OF THE ROLE OF INTANGIBLE AXIS TOWARD THE PATHOK NEGORO'S DESIGN CONCEPT, YOGYAKARTA
}

\author{
Silvia Meliana ${ }^{1 *}$; Octaviana Sylvia Caroline² \\ ${ }^{1,2}$ Interior Design Department, School of Design, Bina Nusantara University \\ Jl. K.H. Syahdan No. 9, Palmerah, Jakarta 11480, Indonesia \\ 'silvia.meliana@ binus.ac.id; ${ }^{2}$ baby@binus.ac.id
}

Received: $30^{\text {th }}$ June 2020/ Revised: $14^{\text {th }}$ July 2020/ Accepted: 03 ${ }^{\text {rd }}$ August 2020

How to Cite: Meliana, S., \& Caroline, O. S. (2020). A review of the role of intangible axis toward the Pathok Negoro's design concept, Yogyakarta. Humaniora, 11(3), 169-175. https://doi.org/10.21512/humaniora.v11i3.6540

\begin{abstract}
The research aimed to review the role of the 'mystical' imaginary axis in Javanese cosmology in the Yogyakarta that might affect the inner spaces of the Pathok Negoro mosques (Ploso Kuning, Babadan, Dongkelan, and Mlangi). The research question was how Yogyakarta's imaginary axis affected the inner spaces of these four Pathok Negoro. Yogyakarta was known to have a unique Javanese cosmology, cultural, and social life character compared to several cities on the island of Java. Yogyakarta kept a harmonious power between human life and the universe and still hold strong Javanese animism and was still tightly coupled with the city's modern life. Human harmony with the universe was seen in the axis of a city that consisted of two main axes in the direction of the compass, namely north to south and east to west. The research applied a qualitative method by doing a literature study and observation. The research shows that the imaginary axis plays an essential role in Yogyakarta's urban design and creates a sustainable concept of the four Pathok Negoro. However, it is not directly involved in the order of the inner space of the architecture design of each mosque.
\end{abstract}

Keywords: intangible axis, Yogyakarta cosmology, pathok negoro mosques, mosque design concept, sustainable concept

\section{INTRODUCTION}

D. I. Yogyakarta is a provincial level area in Indonesia, located in the southern part of Java island and bordered by Central Java province. Based on Law No. 13 of 2012, Yogyakarta is designated as a special region because it has unique features in urban and cultural spatial. It has historical values not found in other cities in Indonesia.

Yogyakarta has a unique morphology of its urban layout with a solid imaginary axis pattern. It is stretching from north to south, marked by mount Merapi in the north and the south coast sea in the south. This imaginary axis is closely related to belief in the relationship between human life and the universe, and human life with God. A specific imaginary axis, which acts as a joint, connects the universe's various cosmic forces. Besides, in the city development plan, this imaginary axis is applied as a road system (Karsono \& Wahid, 2008). Yogyakarta's road system has a stable axis when drawn a straight line from north to south and from west to east that affects trust religious because it is considered a cosmological orientation.

Buildings, roads, monuments, fields, and the physical appearance of the city components that become icons of the city are markers of city culture and civilization. Nevertheless, not all can be called unique if there is no explanation of its features (Suryanto, Djunaedi, Sudaryono, 2015). Figure 1A shows that Yogyakarta's spatial layout that stretches towards the south-north (called the philosophical axis) has a significant philosophical meaning. Its configuration is marked by the presence of spatial and building elements. These elements consist of the KrapyakYogyakarta-Tugu Palace stage, which depicts a microcosm concept, namely the realm of real human life. The Kraton's existence is a city spatial structure transformation of a fundamental concept as a belief system or religion called Sangkan Paraning Dumadi (Widyawati, 2017). 


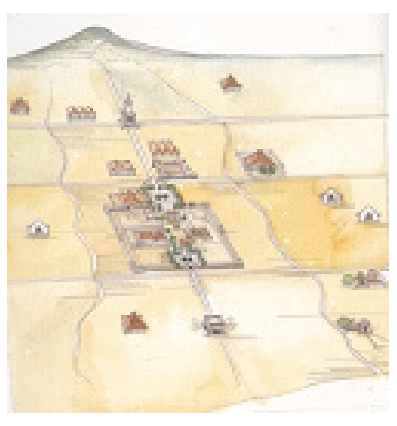

A

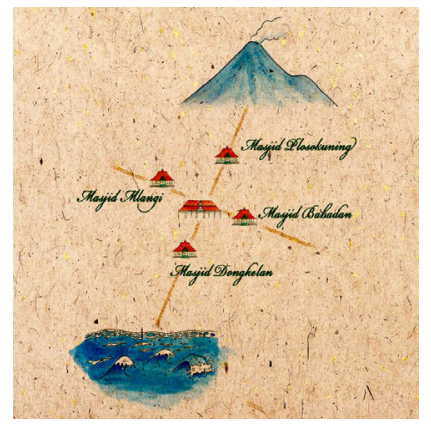

B
Figure 1 A. Philosophical Axis of Yogyakarta City (Balai Pelestarian Cagar Budaya DIY, 2017);

B. Pathok Negoro Mosques (Karaton Ngayogyakarta Hadiningrat, 2016)

The philosophical concept explains where humans originate, and the direction to which they will go from birth proceed through life until finally returning to God. This concept is known in the Javanese language, Sangkan Paraning Dumadi. Figure 1 also illustrates the macrocosm concept, which is the imaginary axis of the south-north marked by the south sea to the north, namely Mount Merapi. An explanation of this imaginary axis is called harmony between humans and God, Manunggaling KawulaGusti (Balai Pelestarian Cagar Budaya DIY, 2017).

Yogyakarta spatial concept is built in 1790 by Sri Sultan Hamengkubuwono I that has extraordinary features. The city layout has a cultural concept called Hamemayu (Memayu) Hayuning Bawono, which has a philosophical meaning to beautify life in the world and maintain it well. This philosophical concept is embodied in the arrangement of city forms known as Catur Gotro Tunggal, namely the Javanese cosmology concept. It maintains harmony between the microcosm and the macrocosm. The concept is seen in the building elements' arrangement in Yogyakarta when it is first built. The establishment of the Kraton is considered a leader, a mosque as a pillar of religion, a market for economic activities, and reflects culture (Suryanto, Djunaedi, Sudaryono 2015). The concept continues to be maintained until the reign of Sri Sultan Hamengkubuwono X. It refers to the concept of sustainable city development, where the Catur Gotro Tunggal or Catursagoto pattern preserves four city landmarks, namely the Palace, Masjid Gedhe, Pasar Gede, and Alun-Alun.

Another specialty found in Yogyakarta, a Kingdom City in the interior, is buildings' existence to maintain the city's defense itself. The four mosques in Yogyakarta's four cardinal directions are believed to maintain the spiritual defense of Yogyakarta. The mosques that are built during the reign of Sri Sultan Hamengkubuwono I are called Pathok Negoro. They are located in the four corners of the city, namely Ploso Kuning, Babadan, Dongkelan, and Mlangi. The philosophy of these mosques' existence is as the backrest of the state's power so that the city will stand firm supported by four Mosques that seem to be the 'Soko Guru' of Yogyakarta. It is a substantial milestone against the state, which is only found in Yogyakarta. It is not found in other cities in Indonesia.

The spatial arrangement of Yogyakarta is also set based on Pathok Negoro (Figure 1B). The location of Pathok Negoro's mosques spread out in the urban periphery of Yogyakarta. Their existence has been regarded as an expression of a philosophical base of the urban boundaries (Suparwoko, Raharjo, \& Mutaqi, 2017). The research aims to review the role of the 'mystical' imaginary axis in Javanese cosmology in Yogyakarta that might affect the inner spaces of the Pathok Negoro. The objective of the research is the inner space of the four Pathok Negoro. The research question is how Yogyakarta's imaginary axis affects the inner spaces of the four Pathok Negoro.

\section{METHODS}

The research applied a qualitative method by doing a literature study and observation for collecting data. The limitation is to look at the philosophy of the imaginary axis found in Yogyakarta and the existence of the four Pathok Negoro. The research looks at the influence of the imaginary axis on the existence of elements of Yogyakarta, especially on the existence of Pathok Negoro as a historic building that gives influence to the development of the city of Yogyakarta.

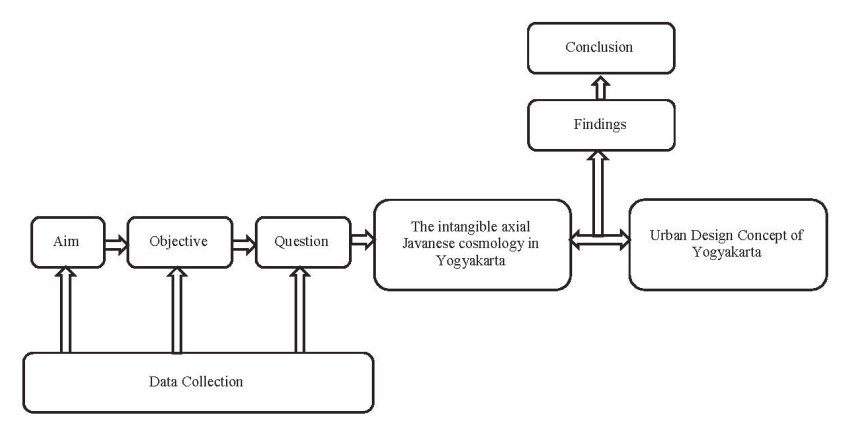

Figure 2 Research Design

Figure 2 shows the research's flow. It starts from the research aim, objective, and question about the intangible axial of Javanese cosmology in Yogyakarta, and the correlation with the urban design concept of Yogyakarta.

\section{RESULTS AND DISCUSSIONS}

Pathok Negoro becomes a new boundary for Yogyakarta's region and becomes one of the distinctive identities of Yogyakarta's unique layout (Suparwoko, Raharjo, \& Mutaqi, 2017). Pathok Negoro mosques are built during the reign of Sultan Hamengkubuwono I, in the period after the construction of Kraton (Royal 
Palace) of Yogyakarta. The development sequence is Mlangi, Ploso Kuning (1724), Dongkelan (1775) by Kyai Nur Iman, and Kyai Mursodo. However, in Dongkelan and Babadan, it is established to Kyai Syihabbuddin for his services to Sultan when in conflict. Pathok Negoro mosques are also part of the region's boundary that has a specialty as the plan of Sultan Hamengku Buwono I (Suparwoko, Raharjo, \& Mutaqi, 2017).

Overall, the mosque incorporated in Pathok Negoro has a function as a center for education, a place for ceremonies and religious activities, and a religious court called the 'Surambi Court'. The mosque's function as the Surambi Court is to make a legal decision on marriage, divorce, or inheritance. The existence of these four mosques is inseparable from maintaining the kingdom's outer defense system. The location of the mosque is on the outskirts of the area so that it becomes a boundary as well as a central defense area outside the kingdom (Karaton Ngayogyakarta Hadiningrat, 2016). The mosque building in Yogyakarta is used for the territorial concept. Pathok Negoro mosque placement in Yogyakarta's urban spatial layout manifests the transcendent concept (Setyowati, Hardiman, \& Murtini, 2018).

The existence of Pathok Negoro is a depiction of harmony between the macrocosm and the microcosm. It is a harmonious relationship between the people and the center of power, also known as Manunggaling Kawula Gusti. In Javanese philosophy, it is known as the papat limo pancer qibla, which is manifested by the existence of the Pathok Negoro's mosques in the four corners of the compass, the center of which is in the Gedhe Mosque, Yogyakarta Palace. This layout concept is called the Mandala concept (Karaton Ngayogyakarta Hadiningrat, 2016).

The concept of Mandala is the concept of world time, namely the four-dimensional classification of space patterned in the four corners of the eye with one center; a concept of human obedience and selfawareness. The existence of the Pathok Negoro's mosques in Yogyakarta is a symbol of the relationship between humans and the universe and its creator. It is believed to be the philosophy of its people's lives and influence the growth of the surrounding culture (Karaton Ngayogyakarta Hadiningrat, 2016).

Pathok Negoro has a high historical value for Yogyakarta, the majority of whom are Muslim. The term kagungan dalem mosque is the mosque that belongs to the Yogyakarta Palace. The term kagungan dalem follows the designation of the position of $\mathrm{Abdi}$ Dalem palace placed in four Pathok Negoro mosques. Azizah (2017) has also argued that Pathok Negoro is a tool to control the Palace's spiritual boundaries and becomes a self-reflection that shows the Yogyakarta palace.

According to Abdullah and Khan (2011), the principal architectural types of Islamic architecture are mosques, the tomb, the palace, and the fort. They have argued about symbolism that is the representation of a thing by the use of symbols. The strength of Islamic art as a whole lies in its ability to synthesize native design elements with imported ones. The water's flow in parks or as a fountain and the plantation of trees are all symbols that depict something. There is no divinity other than God in the fundamental formula of Islam, la ila ha illa lah. It means that God is one and only one, and everything the image Him to be, He is other than (Holy Qur'an) Islamic used to describe the absence of icons in Islamic art. So that the Islamic avoids creating the illusion of living beings (Abdullah \& Khan, 2011). Islamic art places the highest value on the achievement of beauty. Therefore the fundamental mandate of architecture in Islam should be to manifest a purposeful sense of beauty. The meaning of beauty here reflects both require environmental adaptation and express principally through Islamic aesthetics (Ardalan, 1980). Islamic architecture is a symbol of an important role in reflecting the superiority of Allah the Almighty. Islamic art and architecture portray the highest degree of motifs and ornamentation to make auspicious symbols of high quality of aesthetic value (Othman \& Zainal-Abidin, 2011). They have also argued that the decoration of the Islamic art concept is flexible, shown in nature, independent form, material and scale, and how to transform the space ambiance. Those will be the evidence of Muslim communal civilization, which measures the ability of technology level in one region.

The adaptation space in the mosque is part of the sustainable utilization process. The space inside the mosque and the interior have been considering the efficiency and particular scale's effectiveness. The mosque's inner space is commonly used as routine operational systems, such as praying, lecturing, and special events on Islam's big day. Space can be used for the pilgrims, whether men, women, children, or even wedding receptions. So the inner space itself has multifunction for different activities (Adi \& Puspitasari, 2016).

According to Syamsiyah and Muslim (2018), the mosque ornament uses more variety of flora, nature, and religion because it is influenced by the pre-Islamic period (the transition from Hinduism to Islam). The variety of ornamental flora used in buildings has a sacred meaning and symbolizes beauty and goodness. The colors usually used are red, green, yellow, and gold. The variety of natural decorations that appear emphasizes the understanding of the role of the universe and God. There is a dualism cosmology (day and night, male and female), orientation, and topography that is transformed into symbols in the form of water, clouds, light, and sun. Whereas religious decoration forms the relationship between servant and God manifest in symbols that have a meaning of majesty and protection. The layout will be adjusted to the function of the building (Syamsiyah \& Muslim, 2018).

In the main building of the mosque, there is always a mihrab. It separates male and female areas, foyer, pawestren, the side of the room, fence, and blumbang, namely pond. The Pathok Negoro's 
mosques as God's house is described as an ark, a holy house called Baitul-Maqdis. The Pathok Negoro has a gate gapura that comes from the word ghofurrur rahiim, meaning Allah is forgiving. When entering the mosque area, people will always remember that they will enter Allah's house, the most forgiving (Humas Sleman, 2018).

In the yard area, there is always a tree sawo $k e c i k$, which is a symbol that Muslims must always be prejudiced. The number of odd stairs and usually has three means that humans have three stages of faith; faith, Islam, and Ihsan. If humans have done all of these stages, it will occupy a high degree and position as a Kamil human being. It is symbolized by the existence of one roof crowned with mustaka, the symbol of the peak of faith in worship. The symbol of flower gambir is interpreted as a fragrant that is found on the side of mustaka. At the same time, kembang luwih is a symbol of the success of one's faith that can reach the peak of perfection that is heaven. It is also said that there are four Soko Guru and Usuk that are standing tall at the center of the main building. It is a symbol of people who pray for forgiveness, seen as a hand that is praying (Humas Sleman, 2018).

Other elements in the mosque such as water ponds have two meanings, namely as a micro symbolic meaning of the extent of the ocean that is explored by Noah's ark, and also as a symbol to purify themselves because at that time, there is no flow of water and wells (Humas Sleman, 2018). The form and existence of the pool in the mosque building present the concept of urban development by Dutch known as the canal concept (Setyowati, Hardiman, \& Murtini, 2018). The establishment of four mosques known as Pathok Negoro, has the location characteristics because social conditions influence Yogyakarta, where Pathok Negoro has functions and forms that influence each other. When viewed from a function, these mosques' existence is the Keraton mosque under the influence of the Gedhe mosque in Yogyakarta Palace. When viewed from the form, the four mosques have a consistent form since its inception (Abror, 2016).

There are four Pathok Negoro's mosques in Yogyakarta. They are Mlangi mosque that is located seven kilometers southwest of Kraton, Ploso Kuning mosque is located nine kilometers north of Kraton, Dongkelan mosque is located three kilometers south of Kraton, and Babadan is located five kilometers east of Kraton. The Mlangi mosque (Figure 3) is found by Kyai Nur Iman, a brother of Sri Sultan Hamengkubuwono I. It is standing in the Mlangi area around 1758. At first, this mosque has 16 main pillars and is made of teak wood and has four pillars inside. Another feature characteristic of the Pathok Negoro's mosques is mustaka, which has the same shape as other State Pathok Mosques. Servants of the Palace inhabit the Mosque area, i.e., people who serve the King, so this is a sign that the mosque is Kagem Dalem owned by the Palace. Around this time, there are many pesantren, an Islamic boarding school for Islam's development.

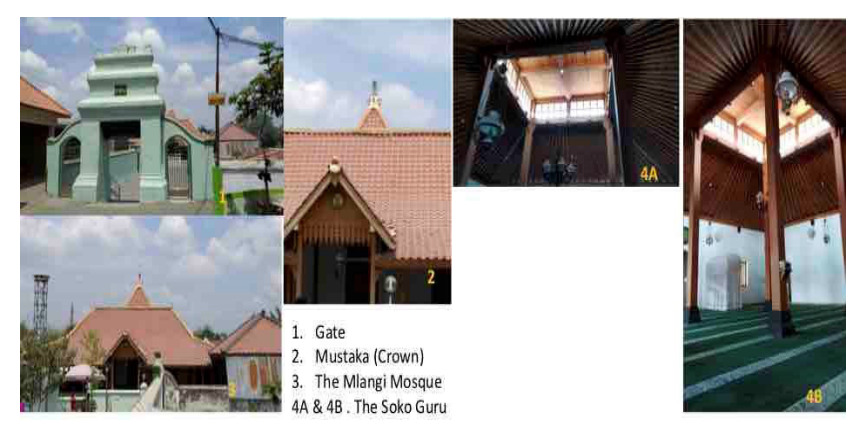

Figure 3 The Mlangi Mosque

(Private Documentation, 2019)

Ploso Kuning (Figure 4A) is located in the northern area of Yogyakarta. It was built in 1724 . This mosque is said to have been built before the Palace of Yogyakarta. It is founded by Kyai Mursodo, the son of Kyai Nur Iman Mlangi. The architecture of the building had changed when Sri Sultan Hamengkubowono I served as King. At that time, Sri Sultan builds the Kraton and the Gedhe mosque in the Kraton neighborhood. He changes the roof model and mustaka or called the head or crown into two stacks or conches to distinguish it from the Gedhe mosque, which has three stacks or three overlaps. Among other Pathok Negoro's mosques, the Ploso Kuning mosque is more authentic. It can be seen in Figure 4.
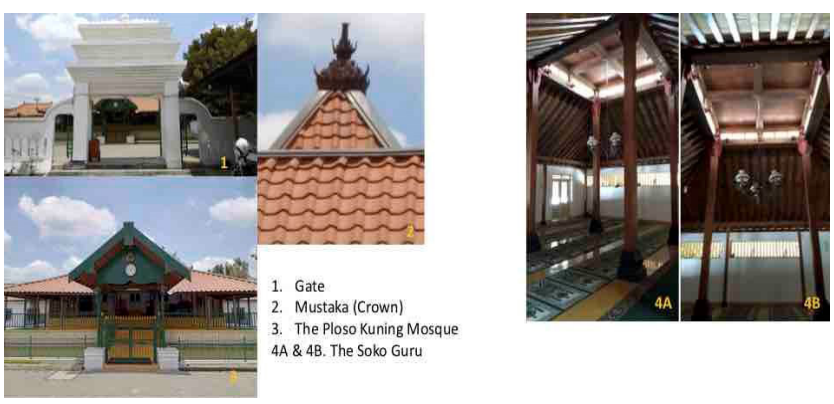

A
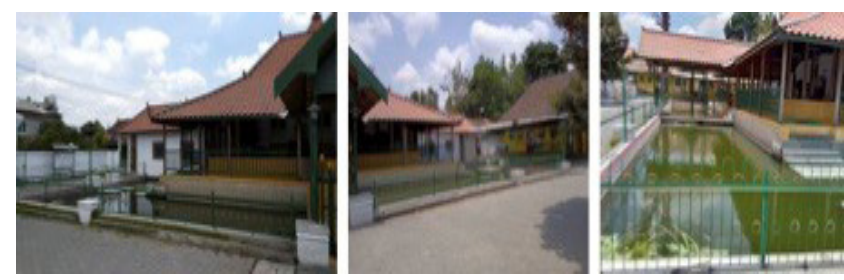

B

Figure 4 A. Ploso Kuning Mosque; B. The Pool of Ploso Kuning Mosque (Private Documentation, 2019)

The uniqueness of the Ploso Kuning mosque is it still has many authenticities since it is built, including the existence of a pool of water that surrounds the mosque. The pool functions to serve the surrounding community's habits, which always clean their feet 
before entering the mosque. Mini pool planning (Figure 4B) is an adaptation of the mosque's building to the surrounding community's culture and habits, which does not use footwear during activities.

The Dongkelan mosque (Figure 5A) in the south is the witness to the defense system during Prince Diponegoro's war against the Dutch. The original building with palm leaves roof is burned down, leaving only the original mustaka made of clay and stored in the mosque. This mosque's architecture is a typical Javanese joglo house with four soko guru (Figure 5B).

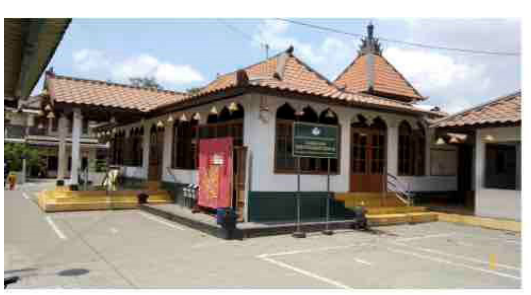

A
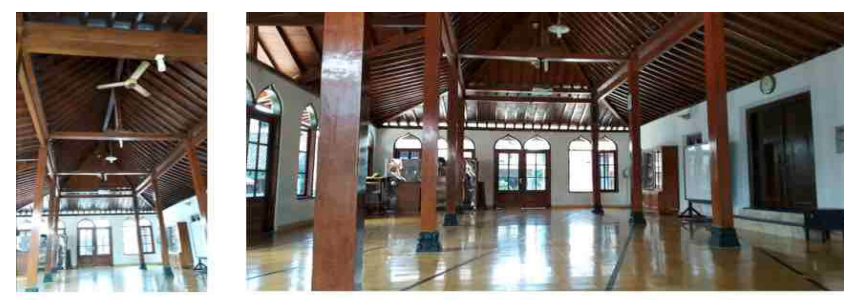

Soko Guru of The Dongkelan Mosq

B

Figure $5 \mathrm{~A}$. The Dongkelan Mosque B. Soko guru of The Dongkelan Mosque (Private Documentation, 2019)

This mosque (Figure 6) is located in Babadan, Bantul, and was built in 1774. The architecture of the building is the same as that of other state Pathok mosques. It has a soko guru and a pool for washing feet and washing. The unique thing about this building is that there is a particular building for women.
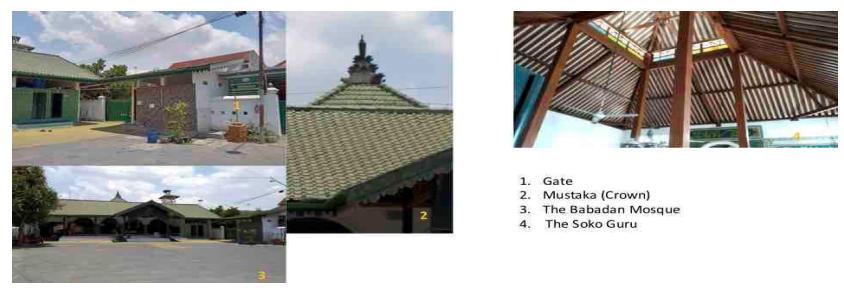

Figure 6 The Babadan Mosque (Private Documentation, 2019)

In this research, Pathok Negoro occurs in varying shapes and sizes as a fundamental part of Yogyakarta's city planning in Muslim culture that possesses the most charge set of visual symbols. A study of the inner space through the Pathok Negoro will deal with the aesthetic concepts and models of the mosque parts. It concerns the issue of constituent forms, surface pattern, color selection, and also material usage. The architecture designs of the mosques at Pathok Negoro are the assimilation of the local wisdom of Javanese architecture and the approach of Islamic architecture. The Islamic architecture approach can be seen in the building's ornament, such as its flora, fauna, nature, and other ornaments.

The local wisdom of Javanese architecture can be seen in the Pathok Negoro's mosques' architectural elements, such as mustaka on top of the tajug roof (a pyramidal element), sorotan at saka columns, and mirong for the columns. Mosque roof structure has symbolic meaning as the first layer of the tajug-shaped roof. It is a symbol of simplicity for the Javanese people and represents the same human degree in God's eyes. The middle layer symbolizes the human that has begun to leave worldly life to get a higher degree in God's eyes because of the better quality of worship. Then the highest level of the roof means that humans have abandoned their worldly life and focus on worshiping to go to heaven (Setyawati, 2016).

The roof forms of a traditional Javanese building are classified into four types based on the community's social status. They are the tajug for the mosque building, joglo for the noble class, and limasan middle, kampung and panggang pe for ordinary people (Cahyandari, 2012).

The symbolic meanings are seen in the outer space layout. Pathok Negoro's mosques are messages of Islamic cultural acculturation philosophy with Javanese vernacular architecture. The mosque is part of the spread of Islam by adjusting to local culture. It is visible that what appears in the Pathok Negoro's mosques is a cultural product influenced by the environment, which is the sultanate of Yogyakarta as its center. In general, the mosque is the center of Islamic worship activities from its people's ability. It is the representation of the Muslim community that gives birth to and prospers it. So that what is seen in the Pathok Negoro's mosques is as part of strengthening the existence of the Sultanate of Yogyakarta, and not being part of the city's imaginary axis itself.

When the researcher visited the Pathok Negoro's mosques and the Kauman mosque or Gedhe mosque in November 2019, it was seen that the architecture of the Pathok Negoro's mosques resembles the shape of the Gedhe mosque in the Sultanate of Yogyakarta. It is just that the Pathok Negoro's mosques are a smaller physical form than the Gedhe Mosque. The elements in the Pathok Negoro's mosques can be seen from the spatial principles, the function of the mosque building for the community and its environment, as well as the philosophical meaning of the symbols. It contains in the building as a whole; the gapura, the pond, the three-steps stair, the terrace, the bedug/kenthongan, the main building, the soko guru, the tajuk roof, and the 
mustaka. The Pathok Negoro's mosques environment itself always consists of three areas. They are the main building, the cemetery area, and educational facilities such as Islamic boarding schools that nearby buildings.

Based on data findings, the researchers have found that the imaginary axis does not directly rule for the inner space of the architecture area of the Pathok Negoro. The imaginary axis connects all of the Pathok Negoro horizontally. When it comes to each inner space, the vertical axis's correlation between nature and God based on the Islamic rules take part.

\section{CONCLUSIONS}

The existence of Pathok Negoro's mosques can be developed to become the reference for the implementation of hamemayu hayuning bawono (the conservation of harmony of human, nature, and God relationship). Imaginary axis influences the existence of powerful mosques because it is connected and centered on the Yogyakarta Palace, a microcosm of the lives of Yogyakarta and its King. The philosophical concept that is shown in the existence of the Pathok Negoro's mosques is Keblat Papat Limo Pancer, where the Ploso Kuning, Babadan, Dongkelan, Mlangi mosques become a strong buffer structure in terms of the spiritual and cultural growth of Yogyakarta at the four cardinal directions of the imaginary city of Yogyakarta. It supports the Gedhe mosque in Yogyakarta Palace. The perfection of the message conveyed is the spirit and qualities of a leader or knight.

Physically, the existence of the mosque building that surrounds the Palace of Yogyakarta gives a sign and a significant influence on the unique features of the spatial elements in Yogyakarta. It is because the Special Region of Yogyakarta only owns this landmark.

The research shows that the imaginary axis plays an essential role in Yogyakarta's urban design that creates a sustainable concept of the four Pathok Negoro. However, it is not directly involved in the order of the inner space of each mosque's architecture design. Furthermore, all of the Pathok Negoro exist for decades by maintaining sustainable aspects through design. The sustainability could be achieved by combining the local wisdom into the design and the harmony of human life and the universe. It gives room for the design's order to function well. Future research is essential to study the implementation of the intangible axis in the city guideline related to conservation.

\section{REFERENCES}

Abdullah, T. A., \& Khan, S. (2011). Symbolism in Islamic architecture. In P. S. M. Akhtar (Ed.), Islamic Architecture at the Cross Roads. Delhi: Welworth Book International.
Abror, I. (2016). Aktualisasi nilai-nilai budaya masjid Pathok Negoro. Esensia: Jurnal Ilmu-Ilmu Ushuluddin, 17(1), 63-79. https://doi.org/10.14421/ esensia.v17i1.1279.

Adi, S. M., \& Puspitasari, C. (2016). Mosque as model of learning principles of sustainable architecture. Journal of Islamic Architecture, 4(1), 33-36. http:// dx.doi.org/10.18860/jia.v4i1.3090.

Ardalan, N. (1980). The visual language of symbolic form: A preliminary study of mosque architecture. In J. G. Katz (ed.), Architecture as Symbol and Self-Identity (pp. 18-36). Philadelphia: Aga Khan Award for Architecture.

Azizah, U. (2017). Masjid Pathok Negoro Mlangi: Respon masyarakat Mlangi terhadap renovasi masjid pada tahun 2012. Juspi: Jurnal Sejarah Peradaban Islam, 1(2), 212-222. http://dx.doi.org/10.30829/j. v1i2.934.

Balai Pelestarian Cagar Budaya DIY. (2017). Sumbu filosofi kota Yogyakarta. Retrieved on October $5^{\text {th }}$, 2019 from https://kebudayaan.kemdikbud.go.id/ bpcbyogyakarta/sumbu-filosofis-kota-yogyakarta/.

Cahyandari, G. O. I. (2012). Tata ruang dan elemen arsitektur pada rumah Jawa di Yogyakarta sebagai wujud kategori pola aktivitas dalam rumah tangga. Jurnal Arsitektur Komposisi, 10(2), 103-118. https:// doi.org/10.24002/jars.v10i2.1064.

Humas Sleman. (2018). Masjid Pathok Negoro Sleman. Retrieved on June $29^{\text {th }}, 2020$ from www.youtube. com/watch? $\mathrm{v}=\mathrm{s} 01 \mathrm{bUyv} 7 \mathrm{MiU}$.

Karaton Ngayogyakarta Hadiningrat. (2016). Masjid Pathok Negara sebagai pilar kesultanan Yogyakarta. Retrieved on October 5 $5^{\text {th }}, 2019$ from https://www. kratonjogja.id/tata-rakiting-wewangunan/3/masjidpathok-negara-sebagai-pilar-kasultanan-yogyakarta.

Karsono, B., \& Wahid, J. (2008). Imaginary axis as a basic morphology in the city of Yogyakarta, Indonesia. In International Conference on Built Environment in Developing Countries. Yogyakarta, Indonesia. pp. 187-195.

Othman, R., \& Zainal-Abidin, Z. J. (2011). The importance of Islamic art in mosque interior. Procedia Engineering, 20, 105-109. http://doi:10.1016/j. proeng.2011.11.144.

Setyawati, E. (2016). Keragaman struktur bangunan masjid Islam Jawa (Studi kasus: Bangunan masjid Gedhe Keraton Yogyakarta). In Seminar Sustainable Architecture And Urbanism, Diponegoro University. Semarang, Indonesia. pp. 31-46.

Setyowati, E., Hardiman, G., \& Murtini, T. W. (2018). Pathok Negoro mosque as the form of territorial defense region of Mataram Kingdom of Islam in Jogjakarta. IOP Conference Series: Earth and Environmental Science, 106, 1-6. https://doi.org/10.1088/17551315/106/1/012074.

Suparwoko., Raharjo, W., \& Mutaqi, A. S. (2017). The influence of Pathok Negoro mosques on the city wide dimension of cultural speciality for the future planning and design of Yogyakarta. In Seoul World Architects Congress. Seoul, South Korea. pp. 1-6.

Suryanto., Djunaedi, A., \& Sudaryono. (2015). Aspek 
budaya dalam keistimewaan tata ruang kota Yogyakarta. Jurnal Perencanaan Wilayah dan Kota, 26(3), 230-252. http://dx.doi. org/10.5614\%2Fjpwk.2015.26.3.6.

Syamsiyah, N. R., \& Muslim, A. (2018). Kajian perbandingan gaya arsitektur dan pola ruang masjid Agung Surakarta dan masjid Gedhe Kauman Yogyakarta. Sinektika Jurnal Arsitektur, 15(1), 1-6. https://doi.org/10.23917/sinektika.v15i1.8989.

Widyawati, L. (2017). Semiotik ruang publik kota lama alun-alun selatan Kraton Yogyakarta. Nalars: Jurnal Arsitektur, 16(1), 15-26. https://doi.org/10.24853/ nalars.16.1.15-26. 